\title{
G Antigen 7
}

National Cancer Institute

\section{Source}

National Cancer Institute. GAntigen 7. NCI Thesaurus. Code C104472.

G antigen 7 (117 aa, $\sim 13 \mathrm{kDa}$ ) is encoded by the human GAGE7 gene. This protein may play a role in tumor recognition. 